\title{
Microarray Profiling of Erwinia chrysanthemi 3937 Genes That are Regulated During Plant Infection
}

\author{
Yasushi Okinaka, ${ }^{1}$ Ching-Hong Yang, ${ }^{1}$ Nicole T. Perna, ${ }^{2}$ and Noel. T. Keen ${ }^{1}$ \\ ${ }^{1}$ Department of Plant Pathology and Center for Plant Cell Biology, University of California, Riverside 92521, U.S.A; \\ ${ }^{2}$ Department of Animal Health and Biomedical Sciences, University of Wisconsin, Madison 53706, U.S.A.
}

Submitted 18 March 2002. Accepted 28 March 2002.

\begin{abstract}
Microarray technology was used to identify genes in $\mathrm{Er}$ winia chrysanthemi 3937 that are specifically up- or downregulated in a plant host compared with growth in laboratory culture medium. Several genes were plant down-regulated, and almost all of them were homologues of well-known housekeeping genes, such as those encoding metabolic functions, oxidative phosphorylation components, and transcription or translation processes. On the other hand, almost all of the plant up-regulated genes were involved with specialized functions, including already known or new putative virulence factors, anaerobiosis, iron uptake, transporters or permeases, xenobiotic resistance, chemotaxis, and stress responses to reactive oxygen species and heat. A substantial number of the plant up-regulated genes do not appear to be directly involved in damaging the host, but are probably important in adapting the pathogen to the host environment. We constructed insertion mutations in several of the plant up-regulated $E$. chrysanthemi 3937 genes. Among these, mutations of Bacillus subtilis pps 1, Escherichia coli purU, and Pseudomonas aeruginosa pheC homologues reduced virulence on African violet leaves. Thus, new insights were obtained into genes important in bacterial virulence.
\end{abstract}

Many pathogens of animals and plants survive in unique alternative habitats in which they are likely to employ distinct sets of expressed genes. A current approach to identifying gene sets expressed by organisms in alternative growth environments is microarray gene expression technology (Danchin and Sekowska 2000; DeLisa et al. 2001; Wei et al. 2001). Genes of interest are arrayed as DNA microspots on glass slides or membranes and the arrays are hybridized to labeled cDNAs produced from mRNA of the target organism grown in particular alternative environments. The major advantage of the approach is that, unlike conventional reporter gene or hybridization strategies, microarrays can simultaneously produce relative expression data for thousands of genes in the target organism, and no prior knowledge of the genes or their regulation is required. Microarrays, therefore, represent an appealing approach to identifying bacterial gene sets that are up-regulated by growth in specific environments, and are particularly attractive for studying gene expression by pathogenic bacteria in

Corresponding author: Yasushi Okinaka; Telephone: +909-787-4134; Fax: +909-787-4294; E-mail: okinaka@mail.ecr.edu.

Dr. Noel T. Keen passed away on April 18, 2002.

*The Spotlight logo represents articles that, in the opinion of the senior editor and editor-in-chief, are of special interest to a broad readership. their normal hosts. We report one of the first studies in which microarrays have been used to identify genes that are specifically up-regulated by bacteria in the pathogenic phase compared with growth on laboratory culture media.

Erwinia chrysanthemi 3937 is a soft-rotting plant pathogen in the Enterobacteriaceae family. It attacks a wide range of plant host species and also has been reported to exist in alternative environments such as plant leaf surfaces (Haygood et al. 1982; Perombelon and Kelman 1980), soil (Burr and Schroth 1977; Stanghellini 1982), and rivers and irrigation water (Cother and Gilbert 1990). Accordingly, we have established the goal of utilizing microarray gene expression as a tool to identify gene sets that are specifically expressed by the bacterium in these alternative environments. With prokaryotes, selective gene expression in a certain environment generally implies function in that environment. In this article, we describe initial results defining the $E$. chrysanthemi 3937 gene set expressed during the pathogenic phase in African violet leaves.

\section{RESULTS}

E. chrysanthemi 3937 genomic arrays with approximately 5,000 randomly selected $3-\mathrm{kb}$ clones were prepared. The arrays were hybridized with Cy3-labeled cDNA probes prepared with total RNA from plant-grown bacteria or those cultured in Luria-Bertani (LB) medium (plant-probe or culture-probe, respectively). In each array clone, normalized signal intensity obtained with plant-probe was divided by that with cultureprobe to calculate the plant/culture expression rate ( $\mathrm{P} / \mathrm{C}$ ratio). Based on average $\mathrm{P} / \mathrm{C}$ ratios obtained from replicated hybridization experiments, down-regulated clones $(\mathrm{P} / \mathrm{C} \leq 0.66)$ and up-regulated clones $(\mathrm{P} / \mathrm{C} \geq 1.5)$ were selected as statistically significant with some exceptions. Of the 5,000 E. chrysanthemi 3937 clones analyzed, 74 plant up-regulated clones and 15 down-regulated clones were identified (Fig. 1, Tables 1 and 2). Several plant up- and down-regulated clones were end sequenced and the resulting data were analyzed by BLASTX, BLASTP, and BLASTN searches. Many clone inserts were completely sequenced by sequential primer walking. Clones generally contained two to four open reading frames (ORFs) (Tables 1 and 2), only a few of which had previously been seen in E. chrysanthemi 3937 (argG and pecS [ECH228], pelDE [ECH408], rssA [ECH1], estV [ECH223 and ECH225], $\operatorname{tog} B, k d g M$, and paeX [ECH242]) or the related pathogen $E$. carotovora (prt [ECH235], rsmC [ECH6], and phage invertase [ECH397]) (Chatterjee et al. 2000).

Excepting cases where only single genes occurred in particular clones, we could not definitively assign ORFs that were being up- or down-regulated in the plant until individual ORFs were amplified by polymerase chain reaction (PCR) and rear- 
rayed. Therefore, we amplified 59 interesting ORFs in the plant up-regulated clones by PCR, spotted them onto slide arrays, and performed hybridization experiments to identify plant up-regulated ORFs (Table 2, column 3). In these ORF hybridization experiments, $\mathrm{P} / \mathrm{C}$ ratios higher than those from the parental 3-kb clone (Table 2, column 2) were often obtained. However, some plant up-regulated 3-kb clones missed such strongly expressed ORFs (e.g., ECH11 and ECH503). One reason may be the use of concentrated DNA and low hybridization temperature (see below) with which nonspecific binding was higher than with the original conditions (data not shown). Nevertheless, 48 plant up-regulated ORFs were confirmed by the re-array hybridizations.

Relatively few plant down-regulated clones were observed compared with plant up-regulated clones, and these generally contained housekeeping genes (Table 1). Most of them were related to the TCA cycle/oxidative phosphorylation (ECH109, ECH117, and ECH409), protein synthesis (ECH212, ECH317, ECH327, ECH407, and ECH411), or transcription (ECH 302, ECH312, and ECH410). These results may reflect a general down-regulation of aerobic metabolism and bacterial growth rate in the plant compared to the rich LB culture medium.

Plant up-regulated genes were more numerous in the array experiments (Fig. 1, Table 2), and these were generally not housekeeping genes. Although new putative polygalacturonase (ECH14), protease/peptidase (ECH10, ECH11, ECH146, $\mathrm{ECH} 202, \mathrm{ECH} 314$, and ECH405), and peptide synthase (ECH5, $\mathrm{ECH} 16, \mathrm{ECH} 205$, and $\mathrm{ECH} 211)$ virulence factors were identified as plant up-regulated, the microarray screening has thus far surprisingly not encountered type III secretion ( $h r p$ ) genes, known to secrete putative virulence factors in E. chrysanthemi (López-Solanilla et al. 2001; Yang et al. 2002). This despite the fact that the E. chrysanthemi 3937 hrpG and $h r p N$ genes, arrayed as controls, showed the expected plant up-regulation ( $\mathrm{Ta}-$ ble 2). The $r s m C$ global virulence regulator of E. carotovora (Cui et al. 1999) was observed for the first time in E. chrysanthemi on plant up-regulated clone ECH6, and may indicate that the rsm system functions in E. chrysanthemi.

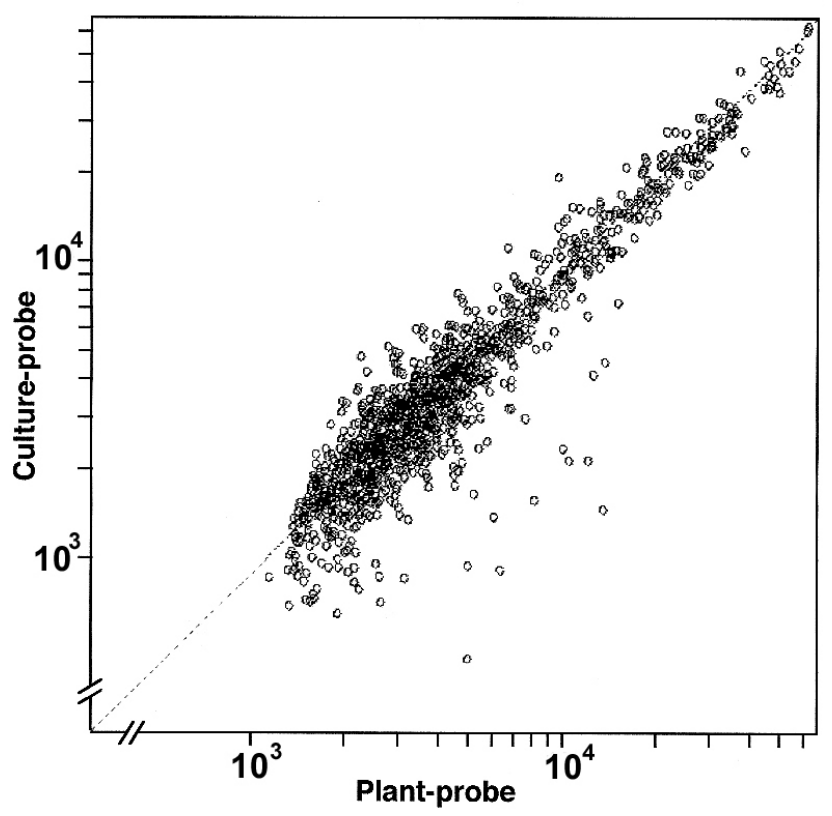

Fig. 1. Log plot of the microarray hybridization signals of random Erwinia chrysanthemi genomic clones obtained using culture- and plantprobes. The signal intensity obtained with plant-probe ( $x$ axis) was plotted against that with culture-probe ( $y$ axis) after signal normalization. These data were derived from a single hybridization experiment.
We failed to encounter iron-uptake genes previously sequenced from E. chrysanthemi (Expert 1999), but observed several new putative iron uptake genes. These included homologues of Escherichia coli fhuA (ECH6) and feoB (ECH11), Pseudomonas aeruginosa pfeA (ECH3), and yfeABCD homologues from Yersinia pestis (ECH123 and ECH126). The plant up-regulated $E$. coli entA homologue (ECH142) is probably a component of the partially characterized cbs operon in Erwinia chrysanthemi that encodes production of the virulencerelated siderophore, chrysobactin (Franza and Expert 1991).

Four different plant up-regulated clones (ECH5, ECH16, $\mathrm{ECH} 205$, and $\mathrm{ECH} 211$ ) showed homology to peptide synthases, known as virulence factors in other bacteria (Gross 1991) but not seen previously in E. chrysanthemi. Several putative xenobiotic resistance genes were identified, including a $P$. aeruginosa $x e n B$ homologue (ECH142, ECH209, and ECH230) and a gene with weak homology to an oxalate/formate antiporter gene (ECH241). Two tellurite resistance gene homologues were plant up-regulated (an Escherichia coli tehB homologue in ECH226 and a $c y s K$ homologue in clone ECH404) (Vásquez et al. 2001). Any physiological role for these genes in virulence is not yet clear. Three phosphotransferase (PTS) system genes, the PtsI and glucose IIA (ECH217), and glucose IIBC (ECH503) components also were identified. These genes will be interesting to study further in view of the well-known role of the PTS system as a global gene regulator in other bacteria (Saier and Reizer 1994). Homologues of the $E$. coli chemotaxis genes $t s r$ (ECH110) and tar (ECH222), and the $r s t A$ and $r s t B$ putative osmolarity sensors (ECH146, ECH308, ECH314, and ECH405) were present on plant up-regulated clones. Putative oxidoreductases, heat shock, and stress protein genes also were identified (ECH7, ECH15, ECH111, ECH123, ECH147, ECH316, ECH406, ECH503, and ECH506), including homologues of the E. coli PerR peroxide resistance regulator protein, the AhpFC alkyl hydroperoxide reductase, and the SpeD S-adenosylmethionine decarboxylase that generates polyamines.

Several recombination/DNA repair genes (homologues of DNA inversion genes [ECH9, ECH229, and ECH307] and $E$. coli ssb [ECH238], recN [ECH12], recF [ECH237], gyrB [ECH237], and mutL [ECH13]) also were plant up-regulated, perhaps an indicator of bacterial stress in the plant environment. Induction of transposase genes (ECH142, 209, 230, and 243) also may be a consequence of bacterial stress in the plant. One clone (ECH110) contained a partial ORF with high homology to the microcin self-immunity protein genes of $E$. coli and Vibrio cholerae. This raises the possibility that Erwinia chrysanthemi may deploy a microcin-similar antibiotic system in host plants (Gonzalez-Pastor et al. 1995). A highly plant upregulated unknown gene (ECH146, ECH308, ЕCH314, and ECH405) with low homology to the Chlamydia hct 2 histonelike gene (Brickman et al. 1993) encoded an unusual lysinerich protein with seven tandem near-perfect 15-amino-acid repeats (PAQKAQAAKKVAKKK). Finally, homologues to two different cardiolipin synthase genes were identified on clones $\mathrm{ECH} 210,229$, and 234. These are of interest because they may imply specific alterations to phospholipid components of the bacterial membrane during growth in a plant host.

Several homologues of Escherichia coli genes showed different linkages in plant up-regulated Erwinia chrysanthemi clones (e.g., pepT and $f e o B$ in ECH11). This probably means that the $E$. chrysanthemi genome will show the extensive mosaic of gene rearrangements relative to Escherichia coli K-12 observed in comparison with E. coli O157:H7 (Perna et al. 2001).

We utilized an in vitro Tn5 insertion strategy to rapidly construct mutations in several ORFs identified as plant up-regulated (Table 2, column 3). Although the number of ORFs thus far mutated is not large, we identified 3 mutants out of 17 
screened that showed clear virulence defects on African violet leaves compared with the wild-type bacteria. A mutation in the Bacillus subtilis peptide synthase homologue on ECH205 showed reduced virulence, although an insertion in the $P$. syringae peptide synthase homologue of $\mathrm{ECH} 211$ did not lead to a reduction in virulence (Fig. 2A). These results may indicate that a cyclic peptide contributes to virulence in Erwinia chrysanthemi, although no previous reports exist. Gene knockouts in the plant up-regulated Escherichia coli purU homologue on ECH1 and the $P$. aeruginosa phe $C$ homologue on ECH233 (Fig. 2B and C) also markedly reduced bacterial virulence of African violet leaves. The biochemical basis for these virulence defects is not known.

\section{DISCUSSION}

The microarray project identified many interesting genes in Erwinia chrysanthemi 3937 that are plant up-regulated relative to growth on LB culture medium (Table 3). It was satisfying to see that plant up-regulated clones generally did not carry housekeeping genes or, if they did, that other gene homologues were present on the same clones that might conceivably contribute to virulence. This implies that the microarray project reliably identified plant up-regulated bacterial genes that may contribute to growth and survival in the plant environment. Two major surprises in the project were the relatively small number of $E$. chrysanthemi plant up-regulated clones carrying known virulence genes and the large number of plant up-regulated genes with homology to known DNA repair and recombination, stress protec- tion, oxidoreductase, xenobiotic degradation, and transporter genes. Accordingly, it is appealing to speculate that many of these latter gene products may favor bacterial growth and development in the plant host environment.

Wassenaar and Gaastra (2001) identified three classes of pathogen virulence genes that are useful for interpreting our microarray data with E. chrysanthemi. Class I virulence genes ("true virulence genes") are directly involved with host interactions, damage the host, are not present in nonpathogenic strains, and frequently are targets for host resistance surveillance. Class I virulence factors include low- and high-molecular-weight toxins, enzymes that attack the structural integrity of host tissue, and damaging proteins that are directed at or into host cells by various secretion systems. Wassenaar and Gaastra also classify class II virulence genes that code for factors which regulate expression of true virulence genes, activate virulence factors by modification or processing, or are required in other ways for the activity of class I factors, such as specific proteases, methylases, chaperones, and so on. Finally, class III virulence genes encode proteins that compromise host defense, cytoskeletal structure, intracellular signaling, or other essential activities, and also include specific transporters, red ox protectant systems, xenobiotic degraders, osmosensors, $\mathrm{pH}$ regulators, and other devices required for the pathogen to cope with the spartan and generally hostile environments found within hosts. One major distinction is that, unlike true housekeeping genes, class III virulence genes are expected to be upregulated in the host environment compared with growth of the pathogen on laboratory culture media.

Table 1. Characteristics of plant down-regulated Erwinia chrysanthemi 3937 clones

\begin{tabular}{|c|c|c|c|c|c|}
\hline Clone ID $^{\mathrm{a}}$ & $\mathbf{P} / \mathrm{C}$ ratio $^{b}$ & Gene $^{c}$ & Homologous gene (organism)/protein ID $^{d}$ & Expectation & Feature of homologous gene \\
\hline \multirow[t]{2}{*}{ ECH109 } & 0.7 & 1 & cyoB $($ E. coli $) / \mathrm{P} 18401$ & $2 e-93$ & Cytochrome o ubiquinol oxidase \\
\hline & & 2 & cyoE $($ E. coli $) / \mathrm{P} 18404$ & $3 e-49$ & CyoE/heme O synthase \\
\hline \multirow[t]{2}{*}{ ECH117 } & 0.7 & 1 & ubiB (E. coli)/P27854 & 0 & Unknown protein \\
\hline & & 2 & ubiE $($ E. coli $) / \mathrm{P} 27851$ & $5 e-50$ & Ubiquinone or menaquinone synthesis \\
\hline ECH120 & 0.6 & 1 & PA0283 (Pseudomonas aeruginosa)/C83610 & $6 e-77$ & Sulfate-binding protein precursor \\
\hline \multirow[t]{3}{*}{$(2.95 \mathrm{~kb})$} & & 2 & cysT (Pseudomonas aeruginosa)/B83610 & 0 & Sulfate transport protein \\
\hline & & 3 & cysW (Pseudomonas aeruginosa)/A83610 & 0 & Sulfate transport protein \\
\hline & & 4 & cysA (Pseudomonas aeruginosa)/H83609 & $6 e-91$ & Sulfate transport protein \\
\hline \multirow[t]{2}{*}{$\mathrm{ECH} 212$} & 0.5 & 1 & metA $($ E. coli)/P07623 & $4 e-46$ & Methionine biosynthesis \\
\hline & & 2 & rrnD (Salmonella typhimurium)/NA & 0 & 23S rRNA \\
\hline ECH235 & 0.6 & 1 & YPO2876 (Yersinia pestis)/NP 406381.1 & $9 e-32$ & Putative lipoprotein \\
\hline \multirow[t]{3}{*}{$(3.15 \mathrm{~kb})$} & & 2 & $y f g K($ E. coli $) / \mathrm{P} 77254$ & 0 & Putative GTP-binding factor \\
\hline & & 3 & YPO2873 (Yersinia pestis)/NP 406378.1 & $4 e-12$ & Unknown protein \\
\hline & & 4 & prt (Erwinia carotovora)/Q99132 & $4 e-76$ & Extracellular protease \\
\hline \multirow[t]{2}{*}{ ECH302 } & 0.4 & 1 & *rpoB (Salmonella typhimurium)/AAF33499.1 & 0 & DNA-directed RNA polymerase \\
\hline & & 2 & $*$ rpoC $($ E. coli $) / \mathrm{AAC} 43086.1$ & $8 e-87$ & DNA-directed RNA polymerase, $\beta$-subunit \\
\hline \multirow[t]{2}{*}{ ECH312 } & 0.3 & 1 & *rpoC (E. coli)/AAC43085.1 & 0 & DNA-directed RNA polymerase, $\beta$-subunit \\
\hline & & 2 & *rpoB (Salmonella typhimurium)/AAF33499.1 & $5 e-93$ & DNA-directed RNA polymerase \\
\hline \multirow[t]{2}{*}{ ECH317 } & 0.3 & 1 & *prlA (E. coli)/P03844 & 0 & Preprotein translocase, SecY subunit \\
\hline & & 2 & $* r p l F($ E. coli $) / \mathrm{CAA} 25720.1$ & $4 e-15$ & 50S ribosomal subunit protein L6 \\
\hline \multirow[t]{2}{*}{ ECH327 } & 0.4 & 1 & yheM $($ E. coli $) / \mathrm{P} 45531$ & $4 e-42$ & Unknown protein \\
\hline & & 2 & fusA (Salmonella typhimurium)/P26229 & 0 & Elongation factor G (see ECH411) \\
\hline \multirow[t]{2}{*}{ ECH402 } & 0.4 & 1 & ytaP (Bacillus subtilis)/B69988 & $4 e-4$ & Unknown protein \\
\hline & & 2 & aceF $($ E. coli $) / \mathrm{P} 06959$ & 0 & Dihydrolipoamide acetyltransferase \\
\hline \multirow[t]{2}{*}{ ECH407 } & 0.4 & 1 & *rpsK $($ E. coli $) / \mathrm{NP} 289858.1$ & $4 e-35$ & $30 \mathrm{~S}$ ribosomal subunit protein $11 \mathrm{~S}$ \\
\hline & & 2 & $* y h d N($ E. coli $) / \mathrm{P} 36677$ & $7 e-29$ & Unknown protein \\
\hline ECH409 & 0.6 & 1 & $\operatorname{acnB}($ E. coli $) / \mathrm{P} 36683$ & 0 & Aconitate hydratase 2 \\
\hline ECH410 & 0.3 & 1 & rpoC (E. coli)/AAC43086.1 & $5 e-83$ & DNA-directed RNA polymerase, $\beta$-subunit \\
\hline \multirow[t]{3}{*}{ ECH411 } & 0.5 & 1 & fusA (Salmonella typhimurium)/P26229 & 0 & Elongation factor G (see ECH327) \\
\hline & & 2 & bfd (Yersinia pestis)/NP 403857.1 & $3 e-19$ & Bacterioferritin-associated ferredoxin \\
\hline & & 3 & bfr (Serratia marcescens) 068935 & $6 e-43$ & Bacterioferritin \\
\hline ECH412 & 0.5 & 1 & No matching gene & & \\
\hline
\end{tabular}

a Clone inserts for which molecular sizes are shown were completely sequenced.

b Arrays of E. chrysanthemi 3937 random genomic clones (approximately 3-kb inserts amplified by polymerase chain reaction) were hybridized with plantor culture-probe. The hybridization signal intensity obtained with plant-probe was divided by that from culture-probe in order to obtain the P/C ratio.

${ }^{c}$ Expected gene number in a candidate clone based on BLASTX, BLASTP, and BLASTN searches (version 2.0 at the NCBI site). The BLAST searches were done against all GenBank sequences. Each gene number corresponds to one gene.

${ }^{\mathrm{d}}$ Genes with the highest scores in the blast searches are listed. The asterisks in a clone indicate the same gene organization as in Escherichia coli. NA = not available. 
Table 2. Characteristics of plant up-regulated Erwinia chrysanthemi 3937 clones

\begin{tabular}{|c|c|c|c|c|c|c|}
\hline \multirow[b]{2}{*}{ Clone ID ${ }^{\mathbf{b}}$} & \multicolumn{2}{|c|}{$\mathrm{P} / \mathrm{C}$ ratio $^{\mathrm{a}}$} & \multirow[b]{2}{*}{ Gene $^{\mathrm{e}}$} & \multirow[b]{2}{*}{ Homologous gene (organism)/protein $\mathrm{ID}^{\mathrm{f}}$} & \multirow[b]{2}{*}{ Expectation } & \multirow[b]{2}{*}{ Feature of homologous gene } \\
\hline & $3 \mathbf{k b}^{\mathbf{c}}$ & ORF $^{d}$ & & & & \\
\hline ECH1 & 2.4 & & 1 & PM0935 (Pasteurella multocida)/AAK03019.1 & $1 \mathrm{e}-52$ & Unknown protein \\
\hline \multirow[t]{3}{*}{$(2.84 \mathrm{~kb})$} & & 2.1 & 2 & + purU (E. coli)/ $\mathrm{P} 37051$ & 0 & Formyltetrahydrofolate deformylase \\
\hline & & & 3 & ychJ $($ E. coli $) / \mathrm{P} 37052$ & $1 \mathrm{e}-19$ & Unknown protein \\
\hline & & & 4 & rssA (Erwinia chrysanthemi)/CAC44354.1 & 0 & Two-component response regulator \\
\hline $\mathrm{ECH} 3$ & 1.2 & & 1 & yxeQ (Bacillus subtilis)/P54956 & $1 e-60$ & Unknown protein \\
\hline \multirow[t]{2}{*}{$(2.84 \mathrm{~kb})$} & & & 2 & N/A (Salmonella typhimurium)/AAC15463.1 & $8 \mathrm{e}-18$ & Putative $X y l S / A r a C$ transcriptional activator \\
\hline & & 2.8 & 3 & pfeA (Pseudomonas aeruginosa)/Q05098 & $6 e-61$ & Ferric enterobactin receptor \\
\hline \multirow{3}{*}{$\begin{array}{l}\text { ECH5 } \\
(3.06 \mathrm{~kb})\end{array}$} & 1.3 & & 1 & ORF4 (Acinetobacter sp.)/CAA05331.1 & $1 e-20$ & Acyl-CoA dehydrogenase \\
\hline & & & 2 & $\begin{array}{l}\text { CAC2192 (Clostridium acetobutylicum)/NP } \\
348809.1\end{array}$ & $2 \mathrm{e}-4$ & Lactoylglutathione lyase \\
\hline & & 1.3 & 3 & surfAB (Bacillus subtilis)/Q04747 & $4 e-31$ & Surfactin synthase subunit 2 \\
\hline \multirow{2}{*}{$\begin{array}{l}\text { ECH6 } \\
(2.97 \mathrm{~kb})\end{array}$} & 2.2 & 1.8 & 1 & fhuA $($ E. coli)/P06971 & $6 e-97$ & Ferrichrome-iron receptor \\
\hline & & & 2 & rsmC (Erwinia carotovora)/AAF01688.1 & $4 \mathrm{e}-10$ & Global regulatory protein \\
\hline \multirow{2}{*}{$\begin{array}{l}\mathrm{ECH} 7 \\
(3.08 \mathrm{~kb})\end{array}$} & 1.7 & 2.1 & 1 & + yajO $($ E. coli $) / \mathrm{P} 77735$ & $5 e-46$ & NAD(P)H-dependent xylose reductase \\
\hline & & & 2 & ompA (E. coli)/P02936 & $2 e-41$ & Outer membrane protein A \\
\hline ECH9 & 7.0 & & 1 & aldB (E. coli)/P37685 & 0 & Aldehyde dehydrogenase B \\
\hline \multirow[t]{2}{*}{$(2.74 \mathrm{~kb})$} & & 1.5 & 2 & pivMB (Moraxella bovis)/P20665 & $4 e-35$ & DNA inversion/pilin gene inverting protein \\
\hline & & & 3 & xylB (E. coli)/P09099 & $3 e-22$ & Xylulokinase \\
\hline \multirow{4}{*}{$\begin{array}{l}\text { ECH10 } \\
(2.84 \mathrm{~kb})\end{array}$} & 1.8 & 3.9 & 1 & CC2809 (Caulobacter crescentus)/AAK24773.1 & $3 e-63$ & Peptidase \\
\hline & & & 2 & N/A (Mycobacterium tuberculosis)/B70686 & $4 e-32$ & Unknown protein \\
\hline & & & 3 & yeiW $($ E. coli $) / \mathrm{P} 58039$ & $3 e-31$ & Unknown protein \\
\hline & & & 4 & yeiP $($ E. coli $) / \mathrm{P} 33028$ & $2 e-92$ & Putative elongation factor $\mathrm{P}$ \\
\hline \multirow{2}{*}{$\begin{array}{l}\text { ECH11 } \\
(2.56 \mathrm{~kb})\end{array}$} & 2.7 & 1.6 & 1 & pepT (E. coli)/P29745 & 0 & Putative peptidase $\mathrm{T}$ \\
\hline & & 1.6 & 2 & feoB (E. coli)/P33650 & $3 e-42$ & Ferrous iron transport protein B \\
\hline \multirow[t]{3}{*}{$\begin{array}{l}\text { ECH12 } \\
(2.44 \mathrm{~kb})\end{array}$} & 5.4 & & 1 & ${ }^{*} y f j B($ E. coli)/P37768 & $7 e-27$ & $\begin{array}{l}\text { Probable inorganic polyphosphate/ATP- } \\
\text { NAD kinase }\end{array}$ \\
\hline & & 2.6 & 2 & $*+\operatorname{rec} N($ E. coli $) / \mathrm{P} 05824$ & 0 & Recombination and DNA repair \\
\hline & & & 3 & *smpA $($ E. coli $) / \mathrm{P} 23089$ & $2 \mathrm{e}-25$ & Unknown ORF, membrane protein \\
\hline \multirow{2}{*}{ ECH13 } & 1.8 & & 1 & mutL $($ E. coli $) / \mathrm{P} 23367$ & $8 e-31$ & Mismatch repair protein \\
\hline & & 1.2 & 2 & hflX $($ E. coli $) / \mathrm{P} 25519$ & $7 \mathrm{e}-80$ & GTP-binding protein \\
\hline \multirow[t]{4}{*}{$\begin{array}{l}\text { ECH14 } \\
(3.29 \mathrm{~kb})\end{array}$} & 2.9 & & 1 & $\begin{array}{l}\text { AGR pAT } 127 \text { (Agrobacterium tumefaciens)/NP } \\
396022.1\end{array}$ & $5 e-9$ & Unknown protein \\
\hline & & & 2 & ECs3633 (E. coli)/NP 311660.1 & 0 & Unknown protein \\
\hline & & & 3 & ygcM (E. coli)/Q46903 & $2 e-62$ & $\begin{array}{l}\text { Putative 6-pyruvoyl tetrahydrobiopterin } \\
\text { synthase }\end{array}$ \\
\hline & & 1.8 & 4 & picA (Agrobacterium tumefaciens)/P27644 & $2 \mathrm{e}-13$ & Polygalacturonase \\
\hline \multirow{4}{*}{$\begin{array}{l}\text { ECH15 } \\
(2.51 \mathrm{~kb})\end{array}$} & 9.5 & & 1 & yhdY $($ E. coli)/P45768 & $5 e-23$ & Hypothetical amino acid $\mathrm{ABC}$ transporter \\
\hline & & & 2 & gltJ $($ E. coli $) / \mathrm{P} 41074$ & $1 e-21$ & Glutamate/aspartate permease \\
\hline & & 2.6 & 3 & $+y d f G($ E. coli $) / \mathrm{P} 39831$ & $5 e-32$ & Putative oxidoreductase \\
\hline & & & 4 & No matching gene & & \\
\hline ECH16 (1.20 kb) & 13.6 & & 1 & pps2 (Bacillus subtilis)/P39846 & $1 \mathrm{e}-90$ & Peptide synthase 2 \\
\hline \multirow{3}{*}{$\begin{array}{l}\text { ECH110 } \\
(2.75 \mathrm{~kb})\end{array}$} & 1.8 & 2.2 & 1 & ggt $($ E. coli $) / \mathrm{P} 18956$ & $2 \mathrm{e}-18$ & Gamma-glutamyltranspeptidase \\
\hline & & & 2 & tsr $($ E. coli)/P02942 & $1 e-62$ & Methyl-accepting chemotaxis protein I \\
\hline & & & 3 & mccF $($ Vibrio cholerae $) / \mathrm{NP} 232833.1$ & $4 \mathrm{e}-11$ & Microcin self-immunity protein \\
\hline ECH111 & 1.4 & W & 1 & CC0481 (Caulobacter crescentus)/P58112 & $7 e-22$ & Pirin-related protein (Apoptosis) \\
\hline$(3.22 \mathrm{~kb})$ & & 2.4 & 2 & + nox $($ Enterococcus faecalis)/P37061 & $4 e-14$ & NADH oxidase (reduces $\mathrm{O}_{2} \rightarrow \mathrm{H}_{2} \mathrm{O}$ ) \\
\hline & & & 3 & $y c f D($ E. coli $) / \mathrm{P} 27431$ & $9 e-65$ & Unknown protein \\
\hline ECH123 & 1.2 & & 1 & dgoT $($ E. coli $) / \mathrm{NP} 418146.1$ & $4 e-26$ & D-Galactonate transport \\
\hline$(2.68 \mathrm{~kb})$ & & 5.2 & 2 & $\operatorname{perR}($ E. coli)/Q57083 & $7 e-36$ & $\begin{array}{l}\text { Peroxide resistance protein (LysR } \\
\text { regulator) }\end{array}$ \\
\hline & & 4.0 & 3 & yfeA (Yersinia pestis)/Q56952 & $3 e-61$ & Periplasmic chelated iron-binding protein \\
\hline ECH124 & 1.6 & & 1 & talB (Salmonella typhimurium)/AAL18971.1 & $2 e-6$ & Transaldolase B \\
\hline & & & 2 & $y c d T($ E. coli)/P75908 & $7 e-26$ & Unknown protein \\
\hline & & & 3 & $\operatorname{mog} A(E$. coli $) / 1 \mathrm{DI} 6 \mathrm{~A}$ & $2 \mathrm{e}-90$ & $\begin{array}{l}\text { Molybdenum cofactor biosynthesis protein, } \\
\text { MogA }\end{array}$ \\
\hline & & & 4 & YPO0465 (Yersinia pestis)/NP 404107.1 & $4 e-5$ & Putative transporter \\
\hline ECH125 & 1.8 & & 1 & YPO1773 (Yersinia pestis)/NP 405340.1 & 0 & Para-aminobenzoate synthase component \\
\hline & & & 2 & STY1956 (Salmonella enterica) / CAD05509.1 & 0 & L-serine deaminase 1 \\
\hline
\end{tabular}

(continued on next page)

${ }^{\text {a }}$ Hybridization signal intensity obtained with plant-probe was divided by that from culture-probe in order to obtain the P/C ratio

${ }^{\mathrm{b}}$ Clone inserts for which molecular sizes are shown were completely sequenced.

${ }^{c}$ Arrays of E. chrysanthemi 3937 random genomic clones (approximately 3-kb inserts amplified by polymerase chain reaction) were hybridized with plantor culture-probe.

${ }^{\mathrm{d}}$ Individual open reading frames (ORFs) identified in the plant up-regulated clones were polymerase chain reaction amplified (0.4 to $1.6 \mathrm{~kb}$ partial ORF fragments), re-arrayed, and hybridized with plant-probe and culture-probe. $\mathrm{W}=$ signals too weak to obtain reliable $\mathrm{P} / \mathrm{C}$ ratios.

${ }^{\mathrm{e}}$ Expected gene number in a candidate clone based on BLASTX, BLASTP, and BLASTN searches (version 2.0 at the NCBI site). The BLAST searches were done against all GenBank sequences. Each gene number corresponds to one gene.

${ }^{\mathrm{f}}$ Genes with the highest scores in the blast searches are listed. The asterisks in a clone indicate the same gene organization as in Escherichia coli; $+=$ genes which were mutated by $\mathrm{Tn} 5$ insertion for virulence assays. NA = not available. 
Table 2. (continued from preceding page)

\begin{tabular}{|c|c|c|c|c|c|c|}
\hline \multirow[b]{2}{*}{ Clone ID $^{\mathbf{b}}$} & \multicolumn{2}{|c|}{$\mathrm{P} / \mathrm{C}$ ratio $^{\mathrm{a}}$} & \multirow[b]{2}{*}{ Gene $^{\mathrm{e}}$} & \multirow[b]{2}{*}{ Homologous gene (organism)/protein $\mathrm{ID}^{\mathrm{f}}$} & \multirow[b]{2}{*}{ Expectation } & \multirow[b]{2}{*}{ Feature of homologous gene } \\
\hline & $3 \mathbf{k b}^{\mathbf{c}}$ & ORF $^{d}$ & & & & \\
\hline ECH126 & 2.3 & & 1 & yfeC (Yersinia pestis)/Q56954 & $3 e-67$ & Chelated iron transport \\
\hline \multirow[t]{3}{*}{$(2.91 \mathrm{~kb})$} & & 2.4 & 2 & yfeD (Yersinia pestis)/Q56955 & $7 e-90$ & Chelated iron transport \\
\hline & & & 3 & mauR (Klebsiella pneumoniae)/P52684 & 0 & Malonate utilization transacting regulator \\
\hline & & & 4 & fabD (Haemophilus influenzae)/P43712 & $5 e-5$ & $\begin{array}{l}\text { Malonyl-CoA-acyl carrier protein } \\
\text { transacylase }\end{array}$ \\
\hline \multirow[t]{2}{*}{ ECH128 } & 2.4 & & 1 & orfA (Klebsiella pneumoniae)/АAK29065.1 & $2 e-5$ & IS element (see ECH224) \\
\hline & & & 2 & PA1408 (Pseudomonas aeruginosa)/G83469 & $5 e-27$ & Unknown protein \\
\hline ECH129 & 2.5 & & 1 & ygaA (E. coli)/P37013 & $4 \mathrm{e}-41$ & Putative transcriptional regulator \\
\hline \multirow[t]{2}{*}{$(2.73 \mathrm{~kb})$} & & 5.3 & 2 & + roo (Desulfovibrio gigas)/Q9F0J6 & $2 \mathrm{e}-78$ & Rubredoxin oxidase-rubredoxin fusion \\
\hline & & & 3 & rubB $($ Acinetobacter calcoaceticus)/P42454 & 0 & Rubredoxin-NAD(+) reductase \\
\hline ECH130 & 5.8 & & 1 & ybgJ (E. coli)/P75744 & $5 e-7$ & Unknown protein \\
\hline \multirow[t]{2}{*}{$(2.41 \mathrm{~kb})$} & & 2.6 & 2 & RSp0931 (Ralstonia solanacearum)/NP 522492.1 & $5 e-78$ & $\begin{array}{l}\text { Amino acid binding periplasmic protein, } \\
\text { transporter }\end{array}$ \\
\hline & & & 3 & SMc02371 (Sinorhizobium meliloti)/NP 385133.1 & $1 \mathrm{e}-48$ & Unknown protein \\
\hline ECH131 & 5.2 & & 1 & ybjT $($ E. coli $) / \mathrm{P} 75822$ & $1 \mathrm{e}-23$ & Putative dTDP-glucose enzyme \\
\hline \multirow[t]{2}{*}{$(3.27 \mathrm{~kb})$} & & 9.8 & 2 & her (Yersinia pestis)/CAC 90188.1 & 0 & Putative oxidoreductase (Ferredoxin) \\
\hline & & 10.4 & 3 & + hcp $($ Yersinia pestis)/CAC 90189.1 & 0 & $\begin{array}{l}\text { Prismane homolog (only exp. during } \\
\text { anaerobic growth) }\end{array}$ \\
\hline \multirow[t]{2}{*}{ ECH136 } & 1.3 & & 1 & PA3782 (Pseudomonas aeruginosa)/F83172 & $6 e-22$ & Probable transcriptional regulator \\
\hline & & & 2 & hipA (E. coli)/P23874 & $1 \mathrm{e}-50$ & DNA biosynthesis regulation \\
\hline \multirow{2}{*}{$\begin{array}{l}\text { ECH139 } \\
(3.11 \mathrm{~kb})\end{array}$} & 1.6 & 1.0 & 1 & y4op (Sinorhizobium fredii)/AAC02677.1 & $2 \mathrm{e}-44$ & Suger $A B C$ transporter binding protein \\
\hline & & 2.0 & 2 & yceE $($ E. coli $) / \mathrm{P} 25744$ & 0 & $\begin{array}{l}\text { Drug MFS-transporter, } \\
\text { fosfomycin\&deoxycholate }\end{array}$ \\
\hline ECH140 & 2.2 & & 1 & lin2949 (Listeria innocua)/CAC98174.1 & $7 e-21$ & Putative transport protein \\
\hline$(1.48 \mathrm{~kb})$ & & & 2 & ytfD (Bacillus subtilis)/F69991 & $5 e-55$ & $\mathrm{~N}$-Acylamino racemase homolog \\
\hline ECH142 & 1.9 & 1.8 & 1 & xenB (Pseudomonas aeruginosa)/D83102 & $4 \mathrm{e}-87$ & Xenobiotic reductase; Fe protein \\
\hline$(3.03 \mathrm{~kb})$ & & & 2 & TnpA1 (Pseudomonas fluorescens)/CAB87819.1 & $3 e-78$ & Transposase \\
\hline & & & 3 & $y$ diI $($ E. coli $) / \mathrm{P} 77781$ & $3 e-48$ & Unknown protein \\
\hline & & 1.9 & 4 & entA $($ E. coli $) / \mathrm{P} 15047$ & $8 \mathrm{e}-49$ & Enterobactin synthesis \\
\hline ECH146 & 1.9 & 4.8 & 1 & $+y d g D($ E. coli $) / \mathrm{P} 76176$ & $3 e-79$ & Protease \\
\hline$(2.56 \mathrm{~kb})$ & & 42.3 & 2 & + No matching gene & & Unknown lysine-rich protein \\
\hline & & & 3 & rstB $($ E. coli $) / \mathrm{P} 18392$ & $3 e-36$ & Histidine sensor kinase \\
\hline ECH147 & 1.6 & & 1 & No matching gene & & \\
\hline & & & 2 & $y c d W($ E. coli $) / \mathrm{P} 75913$ & $2 \mathrm{e}-10$ & Putative 2-hydroxyacid dehydrogenase \\
\hline ECH202 & 2.2 & 11.4 & 1 & cds106 (E. coli)/CAA50734.1 & $3 e-35$ & Putative peptidase \\
\hline & & & 2 & $y d d B($ E. coli $) / \mathrm{P} 31827$ & $1 \mathrm{e}-18$ & Unknown protein \\
\hline ECH205 & 5.4 & & 1 & trbI (Ralstonia eutropha)/CAA71794.1 & $1 \mathrm{e}-32$ & Conjugative transfer protein \\
\hline$(2.53 \mathrm{~kb})$ & & & 2 & + pps1 (Bacillus subtilis)/P39845 & $9 e-49$ & Peptide synthase 1 \\
\hline ECH206 & 5.1 & W & 1 & NA (Mus musculus)/P49025 & 0.003 & CITRON protein \\
\hline ECH207 & 2.7 & & 1 & sucA (E. coli)/NP 286442.1 & 0 & 2-Oxoglutarate dehydrogenase \\
\hline ECH209 & 6.2 & 1.8 & 1 & xenB (Pseudomonas aeruginosa)/D83102 & $4 \mathrm{e}-87$ & Xenobiotic reductase; Fe protein \\
\hline$(2.66 \mathrm{~kb})$ & & & 2 & TnpAl (Pseudomonas fluorescens)/CAB87819.1 & $3 e-78$ & Transposase \\
\hline & & & 3 & ydiI $($ E. coli $) / \mathrm{P} 77781$ & $3 e-48$ & Unknown protein \\
\hline $\begin{array}{l}\mathrm{ECH} 210 \\
(3.18 \mathrm{~kb})\end{array}$ & 2.2 & & 1 & *oppD $($ E. coli $) / \mathrm{P} 76027$ & $2 \mathrm{e}-99$ & $\begin{array}{l}\text { Oligopeptide transporter, ATP-binding } \\
\text { protein }\end{array}$ \\
\hline & & & 2 & *oppF (E. coli)/P77737 & 0 & $\begin{array}{l}\text { Oligopeptide transporter, ATP-binding } \\
\text { protein }\end{array}$ \\
\hline & & & 3 & $* y c i U($ E. coli)/P76028 & $6 e-55$ & Unknown protein \\
\hline & & 1.7 & 4 & *cls $($ E. coli $) / \mathrm{P} 31071$ & 0 & Cardiolipin synthase (see ECH229 and 234) \\
\hline ECH211 & 4.5 & & 1 & + syrE (Pseudomonas syringae)/T14593 & $2 \mathrm{e}-57$ & Peptide synthase \\
\hline $\mathrm{ECH} 215$ & 1.6 & & 1 & YPO0874 (Yersinia pestis)/NP 404494.1 & 0 & Unknown protein \\
\hline $\begin{array}{l}\mathrm{ECH} 217 \\
(2.88 \mathrm{~kb})\end{array}$ & 2.3 & 2.2 & 1 & + ptsI (Salmonella typhimurium)/P12654 & 0 & $\begin{array}{l}\text { Phosphoenolpyruvate-protein } \\
\text { phosphotransferase (PTS) }\end{array}$ \\
\hline & & & 2 & $\operatorname{crr}($ E. coli $) / \mathrm{P} 08837$ & $3 e-78$ & Glucose-specific IIA component (PTS) \\
\hline & & 2.9 & 3 & PA2713 (Pseudomonas aeruginosa)/A83307 & $1 e-13$ & Unknown protein \\
\hline ECH219 & 3.6 & & 1 & iluK (Klebsiella pneumoniae)/P27696 & 0 & Acetolactate synthase \\
\hline & & & 2 & aldC (Enterobacter aerogenes $) / \mathrm{P} 05361$ & $4 \mathrm{e}-70$ & alpha-acetolactate decarboxylase \\
\hline & & W & 3 & budR (Klebsiella terrigena)/P52666 & $7 e-49$ & Bud operon transcriptional regulator \\
\hline ECH220 & 2.3 & 4.4 & 1 & yxjG (Bacillus subtilis)/P42318 & $3 e-83$ & Unknown protein \\
\hline$(3.45 \mathrm{~kb})$ & & 1.1 & 2 & brnQ $($ E. coli)/P37011 & 0 & branched-chain amino acid transporter \\
\hline & & & 3 & NA (Salmonella typhimurium)/S35983 & $6 e-96$ & Proline permease \\
\hline ECH222 & 4.2 & & 1 & $\operatorname{tar}($ E. coli $) / \mathrm{P} 07017$ & $3 e-20$ & Methyl-accepting chemotaxis protein II \\
\hline$(2.61 \mathrm{~kb})$ & & & 2 & No matching gene & & \\
\hline & & 1.2 & 3 & orf8 (Pseudomonas denitrificans)/P29941 & $9 e-27$ & Hypothetical cob gene \\
\hline ECH223 & 1.8 & 2.4 & 1 & est $V($ E. chrysanthemi 3937$) / \mathrm{NA}$ & 0 & Esterase \\
\hline$(2.79 \mathrm{~kb})$ & & & 2 & STY2675 (Salmonella enterica)/CAD07669.1 & $1 \mathrm{e}-72$ & Putative amidotransferase \\
\hline & & & 3 & PA0163 (Pseudomonas aeruginosa)/A83625 & $1 \mathrm{e}-23$ & Putative transcriptional regulator \\
\hline $\mathrm{ECH} 224$ & 2.6 & & 1 & valS $($ E. coli $) / \mathrm{P} 07118$ & 0 & Valyl-tRNA synthetase \\
\hline & & & 2 & orfA (Klebsiella pneumoniae)/AAK29065.1 & $2 \mathrm{e}-50$ & Unknown protein (see ECH128) \\
\hline & & & 3 & orfB (Klebsiella pneumoniae)/AAK29066.1 & $6 e-19$ & Unknown protein (see ECH128) \\
\hline & & & & & & (continued on next page) \\
\hline
\end{tabular}


Our microarray results with E. chrysanthemi suggest that class III virulence genes far outnumber class I and II genes and raise the specter that they are more important than previously thought for growth of the pathogen in a plant host. Although a few class III virulence genes have previously been identified in E. chrysanthemi (Hassouni et al. 1999; López-Solanilla et al. 2001; Nachin et al. 2001), our results suggest that many more are present and may contribute to virulence.

We successfully used an in vitro Tn5 insertion approach for rapidly constructing mutations in genes on the microarray clones and then recombining them into the E. chrysanthemi chromosome. Although results are as yet limited, mutations in 3 of 17 plant up-regulated genes were reduced in virulence on African violet leaves (Fig. 2). These include the purU homo- logue in ECH1 and the pheC homologue in ECH233, both appearing to be class III virulence genes. While we do not understand the function of these genes in promoting virulence, the homologues have known biochemical functions. In addition, mutation of a class I peptide synthase homologue in ECH205 led to reduced virulence, perhaps indicating that a previously unknown cyclic peptide contributes to virulence. Significantly, mutation of the peptide synthase homologue in clone ECH211 did not appear to affect virulence, suggesting that E. chrysanthemi may contain at least two different peptide synthase genes. Based on bacterial growth on M9 glucose minimal medium, only the purU mutant out of three reduced virulence strains was revealed to be auxotrophic (unpublished data). This auxotrophic phenotype may have contributed to the re-

Table 2. (continued from preceding page)

\begin{tabular}{|c|c|c|c|c|c|c|}
\hline \multirow[b]{2}{*}{ Clone ID ${ }^{b}$} & \multicolumn{2}{|c|}{$\mathrm{P} / \mathrm{C}$ ratio $^{\mathrm{a}}$} & \multirow[b]{2}{*}{ Gene $^{\mathrm{e}}$} & \multirow[b]{2}{*}{ Homologous gene (organism)/protein ID $^{\mathrm{f}}$} & \multirow[b]{2}{*}{ Expectation } & \multirow[b]{2}{*}{ Feature of homologous gene } \\
\hline & $3 \mathbf{k b}^{\mathrm{c}}$ & ORF $^{d}$ & & & & \\
\hline ECH225 & 2.5 & 6.7 & 1 & + PA5395 (Pseudomonas aeruginosa)/C82971 & $1 \mathrm{e}-61$ & Unknown protein \\
\hline \multirow{2}{*}{$(2.37 \mathrm{~kb})$} & & 2.4 & 2 & + estV $($ E. chrysanthemi 3937$) / \mathrm{NA}$ & 0 & Esterase \\
\hline & & & 3 & yfeJ (Salmonella typhimurium)/P40194 & $2 e-9$ & Unknown protein \\
\hline ECH226 & 2.9 & & 1 & $\operatorname{ygbD}($ E. coli)/P37596 & $5 e-53$ & Rubredoxin reductase \\
\hline \multirow[t]{2}{*}{$(2.72 \mathrm{~kb})$} & & 4.1 & 2 & tehB (E. coli)/P25397 & $7 e-62$ & Tellurite resistance \\
\hline & & & 3 & ribB $($ E. coli)/P24199 & $1 \mathrm{e}-92$ & Riboflavin, FMN and FAD synthesis \\
\hline ECH228 & 4.8 & & 1 & $y d h M($ E. coli $) / \mathrm{P} 76425$ & $1 \mathrm{e}-38$ & Unknown His rich protein \\
\hline \multirow{2}{*}{$(2.90 \mathrm{~kb})$} & & & 2 & $\arg G(E$. chrysanthemi $) / \mathrm{AAF} 74776.1$ & 0 & Argininosuccinate synthase \\
\hline & & & 3 & pecS $($ E. chrysanthemi)/P42195 & 0 & Regulator of pectinase, cellulase, etc. \\
\hline \multirow{3}{*}{$\begin{array}{l}\mathrm{ECH} 229 \\
(2.67 \mathrm{~kb})\end{array}$} & 3.1 & W & 1 & $y b h O(E$. coli $) / \mathrm{P} 75771$ & $2 \mathrm{e}-48$ & Cardiolipin synthase (see ECH210) \\
\hline & & & 2 & pivMB (Moraxella bovis)/P20665 & $5 e-34$ & DNA inversion/pilin gene inverting protein \\
\hline & & & 3 & $y b h L($ E. coli $) / \mathrm{P} 75768$ & $5 e-95$ & Unknown protein \\
\hline \multirow[t]{3}{*}{$\mathrm{ECH} 230$} & 2.9 & 1.8 & 1 & xenB (Pseudomonas aeruginosa)/D83102 & $9 e-36$ & Xenobiotic reductase; Fe protein \\
\hline & & & 2 & TnpA1 (Pseudomonas fluorescens)/CAB87819.1 & $3 e-78$ & Transposase \\
\hline & & & 3 & ydil (E. coli) / $\mathrm{P} 77781$ & $1 \mathrm{e}-34$ & Unknown protein \\
\hline ECH231 & 1.4 & & 1 & Z3973 (E. coli O157:H7)/BAB36957.1 & $9 e-33$ & Putative transcriptional regulator \\
\hline ECH233 $(0.61 \mathrm{~kb})$ & 3.3 & & 1 & + pheC (Pseudomonas aeruginosa)/Q01269 & $8 \mathrm{e}-64$ & $\begin{array}{l}\text { Cyclohexadienyl dehydratase } \\
\text { (phenylalanine synthesis) }\end{array}$ \\
\hline \multirow[t]{2}{*}{ ECH234 } & 1.5 & & 1 & $y b h O($ E. coli)/P75771 & $2 \mathrm{e}-29$ & Cardiolipin synthase (see ECH210 and 229) \\
\hline & & & 2 & $y b h L($ E. coli $) / \mathrm{P} 75768$ & $1 \mathrm{e}-32$ & Unknown protein \\
\hline \multirow{2}{*}{$\begin{array}{l}\text { ECH237 } \\
(2.98 \mathrm{~kb})\end{array}$} & 1.5 & & 1 & *recF $($ E. coli $) / \mathrm{P} 03016$ & $3 e-73$ & ssDNA and ds DNA binding, ATP binding \\
\hline & & & 2 & *gyrB (E. coli $) / \mathrm{P} 06982$ & 0 & $\begin{array}{l}\text { DNA gyrase subunit B, typeII } \\
\text { topoisomerase }\end{array}$ \\
\hline \multirow{4}{*}{$\begin{array}{l}\mathrm{ECH} 238 \\
(3.20 \mathrm{~kb})\end{array}$} & 1.4 & & 1 & No matching gene & & \\
\hline & & & 2 & $\begin{array}{l}\text { SCE20.35. (Streptomyces } \\
\text { coelicolor)/CAB } 65591.1\end{array}$ & $1 \mathrm{e}-6$ & Unknown protein \\
\hline & & & 3 & yddH (E. coli)/P76121 & $2 \mathrm{e}-32$ & Unknown protein \\
\hline & & & 4 & ssb $($ E. coli $) / \mathrm{P} 02339$ & $3 e-52$ & ssDNA binding \\
\hline $\mathrm{ECH} 239$ & 3.2 & 9.1 & 1 & NA (Saccharomyces cerevisiae)/P53750 & $4 \mathrm{e}-42$ & Unknown protein \\
\hline \multirow[t]{3}{*}{$(2.78 \mathrm{~kb})$} & & 2.6 & 2 & $\begin{array}{l}+ \text { SCE } 59.14 \mathrm{c}(\text { Streptomyces } \\
\text { coelicolor)/CAB72201.1 }\end{array}$ & $1 \mathrm{e}-11$ & Unknown protein \\
\hline & & & 3 & PA3034 (Pseudomonas aeruginosa)/A83267 & $5 e-27$ & Putative transcriptional regulator \\
\hline & & 6.7 & 4 & PA5395 (Pseudomonas aeruginosa)/C82971 & $1 \mathrm{e}-61$ & Unknown protein \\
\hline \multirow{3}{*}{$\begin{array}{l}\mathrm{ECH} 240 \\
(2.66 \mathrm{~kb})\end{array}$} & 4.8 & & 1 & wcaJ $($ E. coli $) / \mathrm{P} 71241$ & $8 \mathrm{e}-80$ & Putative colanic acid synthesis \\
\hline & & & 2 & VC0935 (Vibrio cholerae)/E82262 & $1 \mathrm{e}-18$ & Unknown protein \\
\hline & & & 3 & wza (E. coli)/P76388 & $2 \mathrm{e}-14$ & Polysaccharide export protein \\
\hline \multirow[t]{3}{*}{$\mathrm{ECH} 241$} & 2.6 & & 1 & oxlT (Halobacterium sp.)/AAG18775.1 & $3 e-10$ & Oxalate/formate antiporter \\
\hline & & & 2 & oxc $($ E. coli $) / \mathrm{P} 78093$ & $8 \mathrm{e}-7$ & $\begin{array}{l}\text { Probable oxalyl-CoA decarboxylase; } \\
\text { oxalate catabolism }\end{array}$ \\
\hline & & & 3 & b2374 (E. coli)/P77407 & $6 e-44$ & Unknown protein \\
\hline \multirow[t]{3}{*}{$\mathrm{ECH} 242$} & 2.7 & 2.3 & 1 & $\operatorname{tog} B$ (E. chrysanthemi)/CAC44121.1 & 0 & $\begin{array}{l}\text { Transport of oligogalacturonides and } \\
\text { chemotaxis }\end{array}$ \\
\hline & & & 2 & kdgM (E. chrysanthemi)/CAC86224.1 & 0 & Oligogalacturonate specific porin \\
\hline & & 2.1 & 3 & paeX (E. chrysanthemi)/NA & 0 & Pectin acetylesterase \\
\hline \multirow[t]{4}{*}{$\mathrm{ECH} 243$} & 3.9 & & 1 & trbI (Ralstonia eutropha)/CAA71794.1 & $7 e-28$ & Conjugative transfer protein \\
\hline & & & 2 & relB (Vibrio cholerae)/NP 232745.1 & $6 e-8$ & Unknown protein \\
\hline & & & 3 & No matching gene & & \\
\hline & & & 4 & NA $($ E. coli)/AAF76755.1 & $6 e-6$ & Putative transposase, IS30 \\
\hline \multirow[t]{3}{*}{$\mathrm{ECH} 244$} & 3.2 & & 1 & No matching gene & & \\
\hline & & & 2 & int (E. coli)/AAF06962.1 & $2 \mathrm{e}-72$ & P4 integrase-like protein \\
\hline & & & 3 & yjgQ $($ E. coli)/P39341 & $5 e-44$ & Unknown protein \\
\hline \multirow[t]{3}{*}{$\mathrm{ECH} 245$} & 2.5 & & 1 & syd (Yersinia pestis)/NP 404648.1 & $2 \mathrm{e}-60$ & Syd protein (interact with $\mathrm{SecY}$ ) \\
\hline & & & 2 & YPO1033 (Yersinia pestis)/NP 404646.1 & $2 e-22$ & Conserved hypothetical protein \\
\hline & & & 3 & $y g d H(E$. coli $) / \mathrm{NP} 289350.1$ & 0 & Unknown protein \\
\hline
\end{tabular}


duced virulence. Nevertheless, it is possible that the purU mutation conferred true reduced virulence because mutation of the Salmonella typhimurium ptsI homologue (Table 2), which also was auxotrophic, retained full virulence. Mutation of the $P$. aeruginosa phe C homologue (ECH233) in E. chrysanthemi resulted in a prototrophic phenotype on M9 medium but was reduced in virulence. In $P$. aeruginosa, this gene encodes periplasmic prephenate dehydratase (cyclohexadienyl dehydratase), a phenylalanine biosynthetic pathway member (Calhoun et al. 2001). The physiological role for this enzyme in E. chrysanthemi is not understood, but the pheC homologue would appear to represent a class III virulence gene.

Class III virulence genes generally have been neglected to date, perhaps because investigators have tended to focus on class I virulence genes that directly damage hosts. Undoubtedly, many class III genes are redundant or overlapping in function, so they might not be revealed as virulence-impaired in traditional mutant screens. Indeed, in vivo expression approaches such as microarrays probably are required to reveal the presence of many class III virulence genes. Although our results are novel for a bacterial plant pathogen, investigators with plant (Boch et al. in press) and animal (Smith 2000) pathogens have emphasized the use of in vivo expression approaches for the study of class III virulence genes. As the genome sequence of E. chrysanthemi is completed, more extensive microarray gene expression data is accumulated, and relevant mutant strains are constructed, our understanding of class III virulence genes will expand.

Several of the plant up-regulated genes observed in the array experiments are associated with anaerobic growth. For instance, a ferrous iron transporter homologue of the Escherichia coli $f e o B$ gene was plant up-regulated in Erwinia

Table 2. (continued from preceding page)

\begin{tabular}{|c|c|c|c|c|c|c|}
\hline \multirow[b]{2}{*}{ Clone ID ${ }^{b}$} & \multicolumn{2}{|c|}{$\mathrm{P} / \mathrm{C}$ ratio $^{\mathrm{a}}$} & \multirow[b]{2}{*}{ Gene $^{\mathrm{e}}$} & \multirow[b]{2}{*}{ Homologous gene (organism)/protein ID ${ }^{f}$} & \multirow[b]{2}{*}{ Expectation } & \multirow[b]{2}{*}{ Feature of homologous gene } \\
\hline & $\overline{3 \mathbf{k b}^{\mathbf{c}}}$ & $\overline{\text { ORF }^{d}}$ & & & & \\
\hline \multirow[t]{4}{*}{$\overline{\mathrm{ECH} 246}$} & 2.7 & & 1 & NA (Haemophilus influenzae)/NP 043506.1 & $1 \mathrm{e}-47$ & Phage HP1; orf35 \\
\hline & & & 2 & NA (Haemophilus influenzae)/AAK37818.1 & $3 e-24$ & Phage HP2; orf 34 \\
\hline & & & 3 & tfa $($ E. coli $) / \mathrm{NP} 037719.1$ & $1 \mathrm{e}-31$ & Gp29 of bacteriophage HK97 \\
\hline & & & 4 & N/A $($ E. coli)/S18689 & $6 e-24$ & Phage $\mathrm{P} 1$ major tail fiber protein $\mathrm{S}$ \\
\hline \multirow{4}{*}{$\begin{array}{l}\mathrm{ECH} 307 \\
(2.71 \mathrm{~kb})\end{array}$} & 5.5 & & 1 & $\mathrm{~J}$ (Enterobacteria phage P2)/NP 052269.1 & $8 \mathrm{e}-67$ & Major tail sheath protein $(\mathrm{FI})$ \\
\hline & & & 2 & STY1639 (Salmonella enterica)/CAD01885.1 & $1 e-30$ & $\begin{array}{l}\text { Tail fiber assembly protein homolog from } \\
\text { prophage E14 }\end{array}$ \\
\hline & & & 3 & NA $($ E. coli $) / \mathrm{S} 18688$ & $1 \mathrm{e}-39$ & $\mathrm{Sc} / \mathrm{SvO}$, phage $\mathrm{P} 1$ major tail fiber protein $\mathrm{S}$ \\
\hline & & & 4 & NA (Erwinia carotovora)/BAA76528.2 & $2 e-53$ & $\begin{array}{l}\text { DNA-invertase (also E. coli BAB38415.1) } \\
\quad \text { (see ECH502) }\end{array}$ \\
\hline \multirow[t]{3}{*}{ ECH308 } & 3.9 & 42.3 & 1 & No matching gene & & Unknown lysine-rich protein \\
\hline & & & 2 & *rstB $($ E. coli $) / \mathrm{P} 18392$ & $3 e-36$ & Histidine sensor kinase \\
\hline & & & 3 & *rstA $($ E. coli $) / \mathrm{P} 52108$ & $9 \mathrm{e}-72$ & Transcriptional regulator \\
\hline ECH309 & 2.2 & & 1 & atsC (Pseudomonas putida)/AAD31787.1 & $6 e-40$ & ATP binding; sulfate ester transporter \\
\hline$(3.38 \mathrm{~kb})$ & & 3.5 & 2 & PA2336 (Pseudomonas aeruginosa)/NP 251026.1 & $9 \mathrm{e}-81$ & Unknown protein \\
\hline \multirow[t]{3}{*}{ ECH314 } & 3.5 & 4.8 & 1 & $y d g D($ E. coli $) / \mathrm{P} 76176$ & $3 e-79$ & Protease \\
\hline & & 42.3 & 2 & No matching gene & & Unknown lysine-rich protein \\
\hline & & & 3 & rstB $($ E. coli $) / \mathrm{P} 18392$ & $3 e-36$ & Histidine sensor kinase \\
\hline ECH316 & 4.4 & & 1 & CC1790 (Caulobacter crescentus)/AAK23766.1 & $2 \mathrm{e}-14$ & Unknown protein \\
\hline \multirow[t]{3}{*}{$(3.36 \mathrm{~kb})$} & & 2.4 & 2 & $\operatorname{ahpF}($ E. coli $) / \mathrm{P} 35340$ & 0 & $\begin{array}{l}\text { Alkyl hydroperoxide reductase-Peroxide } \\
\text { degrader }\end{array}$ \\
\hline & & & 3 & ahpC (Salmonella typhimurium)/P19479 & $3 e-95$ & Alkyl hydroperoxide reductase C22 \\
\hline & & 1.0 & 4 & hmuU (Yersinia pestis)/Q56992 & $2 \mathrm{e}-24$ & $\begin{array}{l}\mathrm{ABC} \text { transporter (hemin } \mathrm{ABC} \text { transporter in } \\
\text { Dienococcus) }\end{array}$ \\
\hline ECH323 & 5.1 & & 1 & $y d b H($ E. coli $) / \mathrm{P} 52645$ & 0 & Unknown protein \\
\hline \multirow{2}{*}{$(2.62 \mathrm{~kb})$} & & & 2 & ynbE $($ E. coli $) / \mathrm{P} 76075$ & $4 \mathrm{e}-12$ & Unknown protein \\
\hline & & 2.9 & 3 & $+\operatorname{acpD}($ E. coli $) / \mathrm{P} 41407$ & $3 e-84$ & Acyl carrier protein phosphodiesterase \\
\hline \multirow{2}{*}{$\begin{array}{l}\mathrm{ECH} 404 \\
(1.51 \mathrm{~kb})\end{array}$} & 4.7 & 1.7 & 1 & $* \operatorname{cys} Z($ E. coli $) / \mathrm{P} 12610$ & $1 \mathrm{e}-85$ & Sulfate transporter \\
\hline & & 16.7 & 2 & *cysK (Salmonella typhimurium)/P12674 & $2 \mathrm{e}-85$ & Cysteine synthase A \\
\hline \multirow[t]{3}{*}{ ECH405 } & 5.8 & 4.8 & 1 & $y d g D($ E. coli $) / \mathrm{P} 76176$ & $3 e-79$ & Protease \\
\hline & & 42.3 & 2 & No matching gene & & Unknown lysine-rich protein \\
\hline & & & 3 & rstB $($ E. coli $) / \mathrm{P} 18392$ & $3 e-36$ & Histidine sensor kinase \\
\hline ECH406 & 2.2 & 1.9 & 1 & speD (Yersinia pestis)/CAC92642.1 & $2 \mathrm{e}-92$ & S-adenosylmethionine decarboxylase \\
\hline \multirow[t]{2}{*}{$(2.87 \mathrm{~kb})$} & & & 2 & nrdI (Salmonella typhimurium)/Q56109 & $2 \mathrm{e}-38$ & Putative ribonucleotide reductase \\
\hline & & 0.8 & 3 & $n r d E(E$. coli $) / \mathrm{P} 39452$ & 0 & $\begin{array}{l}\text { Ribonucleoside-diphoshpate reductase } 2, \\
\text { alpha subunit }\end{array}$ \\
\hline \multirow[t]{2}{*}{$\mathrm{ECH} 408$} & 2.1 & & 1 & pelE (E. chrysanthemi)/P18210 & 0 & pectate lyase \\
\hline & & & 2 & pelD (E. chrysanthemi)/P18209 & 0 & pectate lyase \\
\hline \multirow{5}{*}{$\begin{array}{l}\text { ЕCH502 } \\
(3.62 \mathrm{~kb})\end{array}$} & 7.6 & & 1 & STY1639 (Salmonella enterica)/CAD01885.1 & $1 \mathrm{e}-30$ & Tail fiber assembly protein homolog \\
\hline & & & 2 & $\mathrm{~J}$ (Enterobacteria phage P2)/NP 052269.1 & 0 & Major tail sheath protein FI (see ECH307) \\
\hline & & & 3 & I (Enterobacteria phage P2)/NP 052270.1 & $3 e-77$ & $\mathrm{P} 2$ tail tube protein FII \\
\hline & & & 4 & $\mathrm{E}$ (Enterobacteria phage $\mathrm{P} 2) / \mathrm{NP} 046781.1$ & $5 e-21$ & Essential tail protein $\mathrm{gpE}$ \\
\hline & & & 5 & No matching gene & & \\
\hline \multirow[t]{2}{*}{$\begin{array}{l}\text { ECH503 } \\
(2.61 \mathrm{~kb})\end{array}$} & 2.7 & 1.6 & 1 & ptsG (E. coli)/P05053 & 0 & $\begin{array}{l}\text { PTS system, glucose-specific IIBC } \\
\text { component (see ECH217) }\end{array}$ \\
\hline & & 1.9 & 2 & N/A (Ralstonia eutropa)/Q07251 & $9 e-45$ & L-lactate dehydrogenase \\
\hline ECH506 & 1.7 & & 1 & *ibpA (E. coli)/P29209 & $7 e-48$ & Heat shock protein $\mathrm{A}$ \\
\hline \multirow[t]{2}{*}{$(2.66 \mathrm{~kb})$} & & 3.5 & 2 & $* i b p B($ E. coli $) / \mathrm{P} 29210$ & $3 e-49$ & Heat shock protein $B$ \\
\hline & & 1.0 & 3 & SODiT1 (Spinacia oleracea)/Q41364 & $1 \mathrm{e}-78$ & 2-Oxoglutarate/malate translocator \\
\hline \multicolumn{7}{|l|}{ Controls } \\
\hline pelD ORF & 19.3 & & & (E. chrysanthemi)/CAA10570.1 & 0 & Pectate lyase \\
\hline$h r p G$ ORF & 5.3 & & & (E. chrysanthemi)/AAC31974.1 & 0 & Component of Hrp secretion system \\
\hline$h r p N$ ORF & 7.2 & & & (E. chrysanthemi)/CAC20124.1 & 0 & Harpin elicitor \\
\hline
\end{tabular}


chrysanthemi (ECH11). Although we do not know if this gene is functional, it is of interest that, in Escherichia coli, the feo $A B$ genes contribute to iron supply under anaerobic conditions and feo mutants are impaired in virulence on mouse (Kammler et al. 1993). The prismane protein homologue (ECH131) is only expressed in E. coli and other facultative anaerobes under anaerobic conditions, and has been suggested to have a role in nitrate/nitrite respiration (van den Berg et al. 2000). A ferredoxin gene was linked to the prismane gene in ECH131. This protein is believed to be involved in assembly of Fe-S reduction proteins in bacteria (Nakamura et al. 1999). Further, a rubredoxin oxidase/rubredoxin hybrid protein gene and an adjacent, probably cotranscribed rubredoxin reductase gene, were plant up-regulated in Erwinia chrysanthemi (ECH129). This raises the possibility that several Fe-S redox proteins may establish an electron shuttle from NADH to oxygen, generating water and reducing the ambient oxygen concentration (Gomes et al. 1997). A NOXase homologue on ECH111 also uses NADH to reduce oxygen directly to water. Finally, it is interesting that several of the plant down-regulated genes in E. chrysanthemi are involved in oxidative phosphorylation, perhaps an indication of conversion to microaerobic growth in the host. Soft-rotting Erwinia spp. have been known to undergo microaerobic conditions in fleshy host tissues such as potato tuber tissues (Perombelon and Kelman 1980; Vayda et al. 1992). It has not been realized that anaerobic conditions also may form in normally infected leaf tissues, but this possibility should be investigated further.

Despite our interesting results in microarray experiments with PCR-amplified clone inserts, several limitations were observed. The complete genome sequence of E. chrysanthemi was not available; therefore, random clone inserts were PCR amplified and arrayed. This approach would fail to reveal any uncloneable genes and some genes may have been over-represented in the library. Clones such as ECH146, ECH308, ECH314, and ECH405 and ECH142, ECH209, and ECH230 encompassed essentially the same DNA segments, whereas most plant up-regulated clones recovered were unique. Therefore, it is likely that we missed several genes in the screen. Recent shotgun sequencing data obtained in the E. chrysanthemi genome project have estimated the genome size as approximately $5.5 \mathrm{Mb}$, which is much larger than expected. Therefore, our 5,000 array clones gave approximately $2.7 \times$ coverage of the genome. We also may have missed some genes not expressed at the 14-h sampling time or for which mRNA turnover was rapid during the infection process, because we selected clones according to reproducibility of the $\mathrm{P} / \mathrm{C}$ expression ratio in replicated experiments using several batches of bacterial RNA. Most plant up-regulated clones also contained more than one ORF. Thus, microarray expression signals were averages of the ORFs on a clone, with a worst scenario being compensating plant up- and down-regulated genes on a single clone leading to little or no net change in gene expression. Such a clone naturally would not be selected for further study. Further, when single ORFs were PCR amplified and re-arrayed, it was often disclosed that their P/C expression ratios were greater than the parent clone. In most cases, this resulted from the presence of a relatively highly expressed constitutive gene on a clone in addition to the plant up-regulated gene. The consequent dilution effect led to a decrease in the observed $\mathrm{P} / \mathrm{C}$ induction ratio for the entire clone insert (Table 2). The use of clones in the project also necessitated considerable DNA sequencing. Individual ORFs then had to be PCR amplified and re-arrayed to positively identify plant up-regulated genes, involving considerable time and expense. We also experienced some problems with amounts of PCR clone inserts arrayed. Variation occurred with hybridization signals between independent arrays and necessitated careful replication of results. Considerable work also was required to recover sufficient bacteria from plant leaves, extract RNA, and prepare labeled cDNAs.

Due to the effort required to analyze clones in the array experiments, we only extracted RNA from bacteria grown in African violet leaves for $14 \mathrm{~h}$. Unique temporal expression patterns can be expected for many virulence-associated genes; therefore, this may have contributed to our failure to isolate some expected genes. For instance, no plant up-regulated hrp genes were isolated, perhaps related to the observed early induction of these genes in E. chrysanthemi (M. Boccara, personal communication).

Most problems associated with the use of clone insert arrays in the current project will be solved by the E. chrysanthemi 3937 genome sequencing project, now underway. When these results are available, it will be possible to construct secondgeneration arrays with gene-specific sequences representing all ORFs in the genome. We also are experimenting with meth-

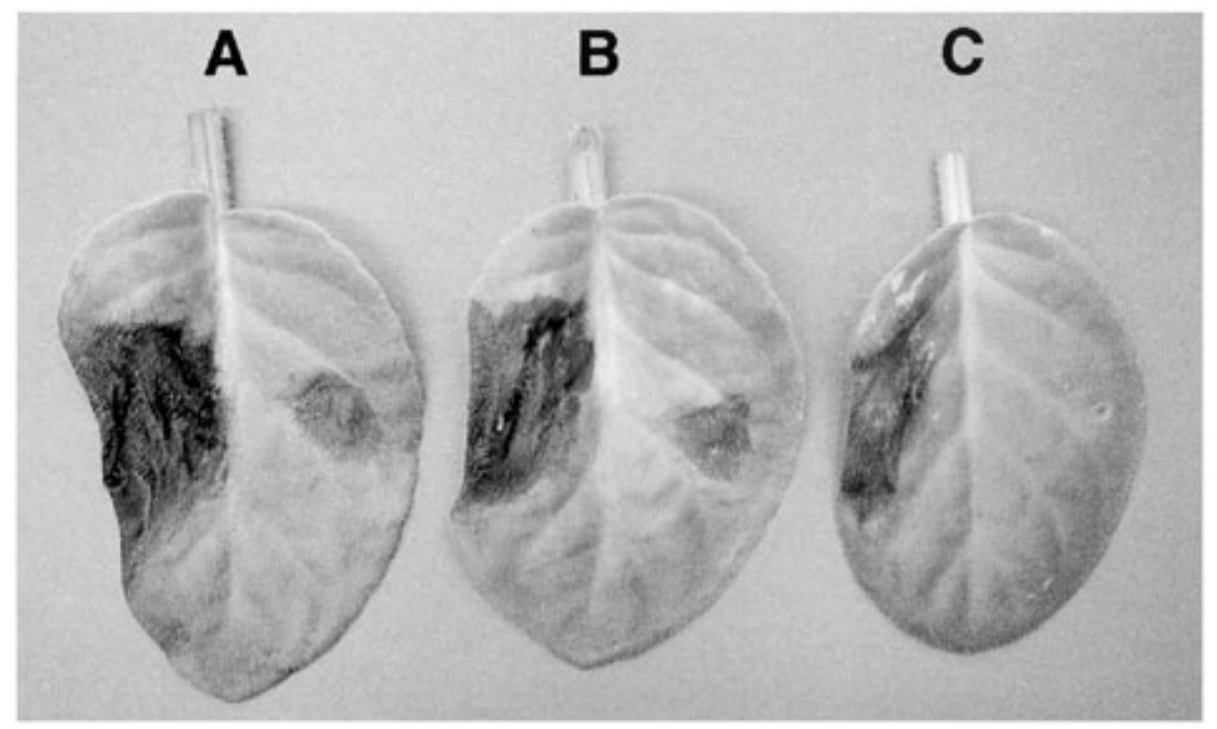

Fig. 2. Symptom phenotypes of three Erwinia chrysanthemi 3937 mutants with reduced virulence. Wild-type E. chrysanthemi 3937 or its mutant strains were inoculated into African violet (var. Katja) leaves (wild type, left; mutant, right). The photos represent symptoms at 40 h after inoculation. A, Bacillus subtilis peptide synthase homologue (ECH205) mutant; B, Escherichia coli purU homologue (ECH1) mutant; and C, Pseudomonas aeruginosa pheC homologue (ECH233) mutant. 
ods permitting bacterial cDNAs to be PCR amplified before hybridizing to the arrays. PCR amplification is generally frowned upon because of the possibility of unequal amplification of cDNAs and the consequent compromise of expression data (Danchin and Sekowska 2000). Although we were able in this study to produce sufficient RNA from E. chrysanthemi cells grown in African violet leaves for preparation of labeled cDNA, considerable time and effort were involved. To utilize microarray global gene expression approaches with E. chrysanthemi in niches where bacterial numbers are very low, such as the surface of plant leaves, will require amplification of cDNAs, and we are working to achieve this.

\section{MATERIALS AND METHODS}

\section{Plant inoculation and cell harvest.}

E. chrysanthemi 3937 cells were cultured in LB medium at $28^{\circ} \mathrm{C}$ and harvested at an $\mathrm{A} 600$ of approximately 0.4 . The cells were washed twice with $50 \mathrm{mM}$ potassium phosphate buffer, $\mathrm{pH} 7.4$, resuspended in the same buffer at $2 \times 10^{7}$ cells $/ \mathrm{ml}$, and used for plant inoculation. African violet (Saintpaulia ionantha var. Katja) plants were grown in soil at $28^{\circ} \mathrm{C}$ with a $16 \mathrm{~h}$ photoperiod of mixed fluorescent and incandescent lighting. The plant leaves were detached, submerged in the cell suspension, and placed in a desiccator and subjected to vacuum. After $10 \mathrm{~min}$, air was readmitted into the desiccator in order to infiltrate bacteria into the leaves. Leaves were washed with distilled water and incubated at $28^{\circ} \mathrm{C}$ for $14 \mathrm{~h}$ after placing the stems in water. Then, the leaves were cut in half, placed into centrifuge tubes specifically designed for this purpose, and centrifuged at $500 \times g$ for $10 \mathrm{~min}$ at $2^{\circ} \mathrm{C}$. Bacteria were forced from the leaves along with intercellular fluids. The resultant bacterial cell suspension was immediately centrifuged at 2,500 $\times g$ for $10 \mathrm{~min}$ at $2^{\circ} \mathrm{C}$ to pellet the bacterial cells, and total RNA was extracted. In the infiltrated leaves, the bacteria multiplied approximately 180 times during the $14 \mathrm{~h}$ incubation.

\section{Synthesis of fluorescent labeled cDNA}

from $E$. chrysanthemi 3937 total RNA.

Total E. chrysanthemi 3937 RNA was extracted from cells grown in culture or plant leaves immediately after pelleting with the RNAeasy Kit (Qiagen Inc., Valencia, CA, U.S.A.).
Total RNA was dissolved in diethylpyrocarbonate (DEPC)treated water and stored at $-80^{\circ} \mathrm{C}$ before use. For probe labeling, $6 \mu \mathrm{g}$ of total RNA was mixed with $100 \mathrm{ng}$ of random hexamer primers, heated at $70^{\circ} \mathrm{C}$ for $10 \mathrm{~min}$, and quickly chilled on ice. The RNA sample $(7 \mu \mathrm{l})$ was mixed with $4 \mu \mathrm{l}$ of $5 \times$ first strand buffer (Life Technologies, Inc., Gaitherburg, MD, U.S.A.), $2 \mu \mathrm{l}$ of $100 \mathrm{mM}$ DTT, $1 \mu \mathrm{l}$ of dNTP mix (dATP, dGTP, dCTP, each at $7.5 \mathrm{mM}$; dTTP at $3 \mathrm{mM}), 2 \mu \mathrm{l}$ of Cy3dUTP (Amersham Pharmacia Biotech, Arlington Heights, IL, U.S.A.) at $25 \mu \mathrm{M}$, and $50 \mathrm{U}$ of SuperscriptII reverse transcriptase (Life Technologies, Inc.). cDNA synthesis was performed at $45^{\circ} \mathrm{C}$ for $80 \mathrm{~min}$ in the dark and then the RNA template was hydrolyzed by incubation with $7.5 \mu$ of $1 \mathrm{~N} \mathrm{NaOH}$ at $70^{\circ} \mathrm{C}$ for $10 \mathrm{~min}$. The reaction was neutralized by adding $\mathrm{HCl}$ and $\mathrm{Cy} 3-$ labeled cDNA was purified by the PCR MinElute Kit (Qiagen Inc.). Labeled probes from culture-grown cells were called culture-probe and those from plant-grown cells, plant-probe.

The vacuum infiltration method for introduction of $E$. chrysanthemi cells into African violet leaves and centrifugal recovery led to substantial amounts of high-quality total RNA from plant-grown bacteria. One hundred infiltrated leaves yielded 20 to $30 \mu \mathrm{g}$ of bacterial RNA. More importantly, the isolated RNA did not contain detectable plant RNA, as determined by agarose gel electrophoresis (data not shown).

\section{Preparation of $E$. chrysanthemi 3937 genomic arrays.}

The E. chrysanthemi genome has not yet been completely sequenced; therefore, we were forced to array random genomic DNA clone inserts. E. chrysanthemi 3937 genomic DNA was isolated and partially digested with Sau3AI. The digested DNA was separated by $1 \%$ agarose gel electrophoresis and fragments (approximately $3 \mathrm{~kb}$ ) were recovered from the gel. The genomic fragments were ligated with the plasmid vector, pBBR1MCS-4 (Kovach et al. 1995) linearized with BamHI, and transformed into Escherichia coli $\mathrm{DH} 5 \alpha$ cells to obtain a genomic library. Approximately 5,000 random library clones (approximately $2.7 \times$ coverage of the genome according to updated data from the E. chrysanthemi genome project) were independently amplified by PCR. For each clone, $25 \mu \mathrm{l}$ of PCR reaction was used, which contained $0.4 \mu \mathrm{M}$ M13 forward and reverse primers (5'CCCAGTCACGACGTTGTAAAACG and 5'-AGCGGATAACAATTTCACAGG, respectively), $12.5 \mu \mathrm{l}$ of $2 \times$ PreMix Buffer

Table 3. Summary of genes identified in plant down- and up-regulated clones

\begin{tabular}{|c|c|c|c|}
\hline Gene regulation & Class & Subclass & Number $^{\mathrm{a}}$ \\
\hline \multirow[t]{3}{*}{ Genes in plant down-regulated clones } & Protein synthesis & & 5 \\
\hline & Transcription & & 5 \\
\hline & TCA cycle/oxidative phosphorylation & & 4 \\
\hline \multirow[t]{20}{*}{ Genes in plant up-regulated clones } & Transport and uptake & Iron transport or uptake & 8 \\
\hline & & Sulfate transport & 2 \\
\hline & & Amino acid or peptide transport & 7 \\
\hline & & Sugar or polysaccharide transport & 6 \\
\hline & & Other transporters & 6 \\
\hline & Chemotaxis & & 3 \\
\hline & Anaerobiosis & & 6 \\
\hline & Regulatory proteinTranscriptional regulators & & 11 \\
\hline & & Translational regulator & 1 \\
\hline & & Other regulatory protein & 3 \\
\hline & Peptide synthesis & & 4 \\
\hline & Degrading enzyme & Pectic enzyme & 4 \\
\hline & & Proteases & 6 \\
\hline & Defense against stress & Xenobiotic resistance & 5 \\
\hline & & Other stress genes & 6 \\
\hline & DNA repair and recombination & & 6 \\
\hline & Transposable element & & 4 \\
\hline & Phage or phage-like component & & 14 \\
\hline & Homologous with unknown protein & & 44 \\
\hline & Open reading frame without significant homologues & & 10 \\
\hline
\end{tabular}

\footnotetext{
${ }^{a}$ Numbers represent total gene numbers shown in Tables 1 and 2.
} 
E (Epicentre Technologies, Madison, WI, U.S.A.) and 2.5 U Taq polymerase (Promega, Madison, WI, U.S.A.). Thirty-five cycles of denaturation at $94^{\circ} \mathrm{C}$ for $1 \mathrm{~min}$, annealing at $55^{\circ} \mathrm{C}$ for $40 \mathrm{~s}$, and extension at $72^{\circ} \mathrm{C}$ for 4 min were performed, followed by 5 min of final extension at $72^{\circ} \mathrm{C}$, were carried out. The PCR products then were purified using a 96-well PCR Purification Kit (Qiagen Inc.) and finally dissolved in $3 \times$ SSC (1× SSC is 0.15 $\mathrm{M} \mathrm{NaCl}$ plus $0.015 \mathrm{M}$ sodium citrate). The obtained DNA samples (50 to $300 \mathrm{ng} / \mu \mathrm{l}$ in $3 \times \mathrm{SSC}$ ) were spotted onto CMTGAPS2 slides (Corning Inc., Corning, NY, U.S.A.) in duplicate using the GMS-417 Microarrayer (Affymetrix Inc., Santa Clara, CA, U.S.A.). In the re-array hybridization using individual ORFs (0.4 to $1.6 \mathrm{~kb}$ ) (Table 2, column 3), all DNA samples were adjusted at $500 \mathrm{ng} / \mu \mathrm{l}$ in $3 \times \mathrm{SSC}$ and spotted onto slides because small DNA fragments generally required high DNA concentration to give good hybridization signals in our hybridization condition.

\section{Microarray hybridizations.}

Labeled probes were dissolved in $40 \mu \mathrm{l}$ of hybridization buffer (3× SSC, 25 mM HEPES, pH 7.0, 0.225\% sodium dodecyl sulfate [SDS], $0.5 \mu \mathrm{g}$ of herring testis DNA) and boiled for $2 \mathrm{~min}$. The probe was immediately applied onto the genomic array slide, covered with a coverslip (Grace Bio-Labs Inc., Bend, OR, U.S.A.), and hybridized at $65^{\circ} \mathrm{C}$ for $16 \mathrm{~h}$ (at $60^{\circ} \mathrm{C}$ for the ORF array experiments). After hybridization, the slide was washed sequentially for 5 min each in $1 \times \mathrm{SSC}-0.1 \%$ SDS, $0.1 \times$ SSC $-0.1 \%$ SDS, and $0.1 \times$ SSC. The slide was dried with centrifugation and fluorescent signals were scanned by the GMS-418 Array Scanner (Affymetrix Inc). Signal strength was quantified by the ImaGene computer program (ver. 4.1; BioDiscovery, Los Angeles), setting the Empty Spot Threshold value at 2.0 to flag spots with low signal/background ratios. Background signals were subtracted using the Local-background command in the GeneSight-Lite program (BioDiscovery) and the data obtained from culture-probe or plant-probe arrays were normalized according to the total signal strength. Normalized signal intensity with plant-probe was divided by that with culture-probe to calculate the $\mathrm{P} / \mathrm{C}$ ratio. $\mathrm{P} / \mathrm{C}$ ratios obtained from individual hybridization experiments were averaged to give the final $\mathrm{P} / \mathrm{C}$ number. Based on standard deviation calculations, clones having $\geq 1.5$ or $\leq 0.66$ final $\mathrm{P} / \mathrm{C}$ ratios were selected as statistically significant plant up-regulated or plant down-regulated, respectively. In initial experiments, some clones with $\mathrm{P} / \mathrm{C}$ ratios of approximately 1.2 to 1.4 or 0.67 to 0.8 were examined further. Hybridization experiments were repeated at least four times for each clone.

\section{Gene knockouts in E. chrysanthemi 3937 and plant virulence assays.}

Selected genes on plant up-regulated microarray clones were mutated by an in vitro Tn5 strategy (EZ::TN <KAN-2> Insertion Kit, Epicentre Technologies). Insertions were physically mapped and precisely located by sequencing from transposon primers. The plasmid constructs then were electroporated into E. chrysanthemi 3937 (Yang et al. 2002) and plasmid curing was accomplished by growth of kanamycin resistant transformants on low-phosphate medium (Ried and Collmer 1987) to select for gene knockouts. Mutations in the resultant kanamycin-resistant and ampicillin-sensitive colonies then were confirmed with isolated DNA by PCR using transposon and target-gene-specific primers.

Virulence assays were conducted on African violet (var. Katja) leaves by the methods described in (Yang et al. 2002). Rates of lesion spreading by mutant E. chrysanthemi 3937 strains were compared with the wild type in at least four different assays to confirm results.

\section{ACKNOWLEDGMENTS}

We thank D. Kehoe (Indiana University) for technical assistance with array hybridizations and J. Chen at the University of California-Riverside (UCR) for technical help with PCR DNA amplification. This project was supported by two grants from the United States Department of Agriculture NRI program and support from the William and S. Sue Johnson Endowment to N. T. Keen was invaluable for the project. We also acknowledge the UCR Genomics Institute and its Core Instrumentation Facility (GICIF) for providing the microarray and data analysis facilities.

\section{LITERATURE CITED}

Boch, J., Joardar, V., Gao, L., Robertson, T. L., Lim, M., and Kunkel, B. N. Identification of Pseudomonas syringae pv. tomato genes induced during infection of Arabidopsis thaliana. Mol. Microbiol. In press.

Brickman, T. J., Barry, C. E., and Hackstadt, T. 1993. Molecular cloning and expression of $h c t B$ encoding a strain-variant chlamydial histonelike protein with DNA-binding activity. J. Bacteriol. 175:4274-4281.

Burr, T. J., and Schroth M. N. 1977. Occurrence of soft-rot Erwinia spp. in soil and plant material. Phytopathology 67:1382-1387.

Calhoun, D. H., Bonner, C. A., Gu, W., Xie, G., and Jensen, R. A. 2001. The emerging periplasm-localized subclass of AroQ chorismate mutases, exemplified by those from Salmonella typhimurium and Pseudomonas aeruginosa. Genome Biol. 2:research0030.1-0030.16.

Chatterjee, A. K., Dumenyo, C. K., Liu, Y., and Chatterjee, A. 2000. Erwinia: Genetics of pathogenicity factors. Pages 236-259 in: Encyclopedia of Microbiology, Vol. 2. J. Lederberg, ed. Academic Press, New York.

Cother, E. J., and Gilbert, R. L. 1990. Presence of Erwinia chrysanthemi in two major river systems and their alpine sources in Australia. J. Appl. Bacteriol. 69:629-738.

Cui, Y., Mukherjee, A., Dumenyo, C. K., Liu, Y., and Chatterjee, A. K. 1999. rsm C of the soft-rotting bacterium Erwinia carotovora subsp. carotovora negatively controls extracellular enzyme and harpin (Ecc) production and virulence by modulating levels of regulatory RNA ( $r s m B$ ) and RNA-binding protein (RsmA). J. Bacteriol. 181:6042-6052.

Danchin, A., and Sekowska, A. 2000. Expression profiling in reference bacteria: Dreams and reality. Genome Biol. 1:1024.1-1024.5.

DeLisa, M. P., Wu, C.-F., Wang, L. Valdes, J. J., and Bentley, W. E. 2001. DNA microarray-based identification of genes controlled by autoinducer 2-stimulated quorum sensing in Escherichia coli. J. Bacteriol. 183:5239-5247.

Expert, D. 1999. Withholding and exchanging iron: Interactions between Erwinia spp. and their plant hosts. Annu. Rev. Phytopathol. 37:307-334.

Franza, T., and Expert, D. 1991. The virulence-associated chrysobactin iron uptake system of Erwinia chrysanthemi 3937 involves an operon encoding transport and biosynthetic functions. J. Bacteriol. 173:68746881.

Gomes, C. M., Silva, G., Oliveira, S., LeGall, J., Liu, M.-Y., Xavier, A. V., Rodrigues-Pousada, C., and Teixeira, M. 1997. Studies on the redox centers of the terminal oxidase from Desulfovibrio gigas and evidence for its interaction with rubredoxin. J. Biol. Chem. 272:22502-22508.

Gonzalez-Pastor, J. E., San Millan, J. L., Castilla, M. A., and Moreno, F. 1995. Structure and organization of plasmid genes required to produce the translation inhibitor microcin C7. J. Bacteriol. 177:7131-7140.

Gross, D.C. 1991. Molecular and genetic analysis of toxin production by pathovars of Pseudomonas syringae. Annu. Rev. Phytopathol. 29:247278.

Hassouni, M. E., Chambost, J. P., Expert, D., Van Gijsegem, F., and Barras, F. 1999. The minimal gene set member $m s r A$, encoding peptide methionine sulfoxide reductase, is a virulence determinant of the plant pathogen Erwinia chrysanthemi. Proc. Natl. Acad. Sci. U.S.A. 96:887-892.

Haygood, R. A., Strider, D. L., and Echandi, E. 1982. Survival of Erwinia chrysanthemi in association with Philodendron selloum, other greenhouse ornamentals, and in potting media. Phytopathology 72:853-859.

Kammler, M., Schon, C., and Hantke, K. 1993. Characterization of the ferrous iron uptake system of Escherichia coli. J. Bacteriol. 175:62126219.

Kovach, M. E., Elzer, P. H., Hill, D. S., Robertson, G. T., Farris, M. A., Roop, R. M., II, and Peterson, K. M. 1995. Four new derivatives of the broad-host-range cloning vector pBBR1MCS, carrying different antibiotic-resistance cassettes. Gene 166:175-176.

López-Solanilla, E., Llama-Palacios, A., Collmer, A., García-Olmedo, F., and Rodríguez-Palenzuela, P. 2001. Relative effects on virulence of mutations in the sap, pel, and hrp loci of Erwinia chrysanthemi. Mol. Plant-Microbe Interact. 14:386-393.

Nachin, L., El Hassouni, M., Loiseau, L., Expert, D., and Barras F. 2001. SoxR-dependent response to oxidative stress and virulence of Erwinia 
chrysanthemi: The key role of SufC, an orphan ABC ATPase. Mol. Microbiol. 39:960-972.

Nakamura, M., Saeki, K., and Takahashi, Y. 1999. Hyperproduction of recombinant ferredoxins in Escherichia coli by coexpression of the ORF1-ORF2-iscS-isc $U$-iscA-hscB-hscA-fdx-ORF3 gene cluster. J. Biochem. 126:10-18.

Perna, N., Plunkett, G., III, Burland, V., Mau, B., Glasner, J. D., Rose, D. J., Mayhew, G. F., Evans, P. S., Gregor, J., Kirkpatrick, H. A., Posfai, G., Hackett, J., Klink, S., Boutin, A., Shao, Y., Miller, L., Grotbeck, E. J., Davis, N. W., Lim, A., Dimalanta, E. T., Potamousis, K. D., Apodaca, J., Anantharaman, T. S., Lin, J., Yen, G., Schwartz, D. C., Welch, R. A., and Blattner, F. R. 2001. Genome sequence of enterohaemorrhagic Escherichia coli O157: H7. Nature 409:529-533.

Perombelon, M. C. M., and Kelman, A. 1980. Ecology of the soft rot Erwinias. Annu. Rev. Phytopathol. 18:361-387.

Ried, J. L., and Collmer, A. 1987. An nptI-sacB-sacR cartridge for constructing directed, unmarked mutations in gram-negative bacteria by marker exchange-eviction mutagenesis. Gene 57:239-246.

Saier, M. H., and Reizer, J. 1994. The bacterial phosphotransferase system: New frontiers 30 years later. Mol. Microbiol. 13:755-764.

Smith, H. 2000. State and future of studies on bacterial pathogenicity: Impact of new methods of studying bacterial behavior in vivo. Pages 265-282 in: Virulence Mechanisms of Bacterial Pathogens, 3rd ed. K. Brogden, J. Roth, T. Stanton, C. Bolin, C. Minion, and M Wannemuehler, eds. American Society for Microbiology Press, Washington, D.C.

Stanghellini, M. E. 1982. Soft-rotting bacteria in the rhizosphere. Pages 249-261 in: Phytopathogenic Prokaryotes, Vol. 1. M. Mount and G.
Lacy, eds. Academic Press, New York.

van den Berg, W. A., Hagen, W. R., and van Dongen, W. M. 2000. The hybrid-cluster protein ('prismane protein') from Escherichia coli. Characterization of the hybrid-cluster protein, redox properties of the [2Fe-2S] and [4Fe-2S-2O] clusters and identification of an associated NADH oxidoreductase containing FAD and [2Fe-2S]. Eur. J. Biochem. 27:666-676.

Vásquez, C. C., Saavedra, C. P., Loyola, C. A., Araya, M. A., and Pichuantes S. 2001. The product of the cysK gene of Bacillus stearothermophilus $\mathrm{V}$ mediates potassium tellurite resistance in Escherichia coli. Curr. Microbiol. 43:418-423.

Vayda, M. E., Antonov, L. S., Yang, Z., Butler, W. O., and Lacy, G. H. 1992. Hypoxic stress inhibits aerobic wound-induced resistance and activates hypoxic resistance to bacterial soft rot. Am. Potato J. 69:239-253.

Wassenaar, T. M., and Gaastra, W. 2001. Bacterial virulence: Can we draw the line? FEMS (Fed. Eur. Microbiol. Soc.) Microbiol. Lett. 201:1-7.

Wei, Y., Lee, J.-M., Richmond, C., Blattner, F. R., Rafalski, J. A., and LaRossa, R. A. 2001. High-density microarray-mediated gene expression profiling of Escherichia coli. J. Bacteriol. 183:545-556.

Yang, C.-H., Gavilanes-Ruiz, M., Okinaka, Y., Vedel, R., Berthuy, I., Boccara, M., Chen, J. W.-T., Perna, N. T., and Keen, N. T. 2002. hrp genes of Erwinia chrysanthemi 3937 are important virulence factors. Mol. Plant-Microbe Interact. 25:472-480.

\section{AUTHOR-RECOMMENDED INTERNET RESOURCE}

The Institute for Genomic Research database: www.tigr.org/tdb/mdb/mdbinprogress.html 